\title{
Derajat Stres Mahasiswa Baru Fakultas Kedokteran Ditinjau Dari Tingkat Penyesuaian Diri Terhadap Tuntutan Akademik
}

\author{
Bania Maulina \\ Ilmu Perilaku (Psikologi), Universitas Islam Sumatera Utara, Indonesia \\ Email: maulinania@yahoo.co.id \\ Dwi Retno Sari \\ Fakultas Kedokteran, Universitas Islam Sumatera Utara, Indonesia \\ Email: dwiretno@gmail.com
}

(Diterima: 05-Desember-2017; direvisi: 06-Februari-2018; dipublikasikan: 24-Juni-2018)

\begin{abstract}
People encounter many changes in the first year of college. It was related to adjustment's problems, which was a serious problem that must be faced when entered college. Adaptation to new environment can make individual experienced stress. The various studies have shown that medical students experienced stress more higher than non-medical program students. Students who are experiencing extreme stress or depressed require serious attention cause it can have an adverse effect on learning process, achievement and even intent to suicide. This research involved 49 medical students. It took to determine the correlation between level of adjustment to academic demands and stress degree on new students in Faculty of Medicine, Islamic University of North Sumatra, T.A 2016-2017. Student Adaptation to College Questionnaire (SACQ) and Kessler Psychological Distress Scale (K10 Test) were used to collect relevant data on adjustment rates and stress levels. Data were analyzed by using Spearman correlation test. The results showed that there was a significant negative correlation between adjustment rates to academic demands with stress level on new students with $\mathrm{p}$ value of 0.001 ( $\mathrm{p}$ $<0.05)$ and $\mathrm{r}$ value of -0.697 .
\end{abstract}

Keywords: medical student; academic adjustment; stress.

Abstrak: Individu mengalami banyak perubahan di tahun pertama kuliah. Ini terkait dengan masalah penyesuaian diri, yang merupakan masalah berat yang harus dihadapi ketika memasuki dunia kuliah. Penyesuaian diri terhadap lingkungan baru dapat membuat individu mengalami stres. Berbagai penelitian menunjukkan bahwa mahasiswa kedokteran mengalami stres yang lebih tinggi jika dibandingkan dengan mahasiswa program studi di sektor non medis. Mahasiswa yang mengalami stres ekstrim dan depresi membutuhkan perhatian serius karena hal ini dapat membawa efek kurang baik terhadap proses pembelajaran, prestasi dan bahkan muncul niat untuk mengakhiri hidup. Penelitian ini melibatkan 49 mahasiswa, dilakukan untuk mengetahui hubungan tingkat penyesuaian diri terhadap tuntutan akademik dan derajat stres pada mahasiswa baru, Fakultas Kedokteran, Universitas Islam Sumatera Utara, T.A 2016-2017. Student Adaptation to College Questionnaire (SACQ) dan Kessler Psychological Distress Scale (K10 Test) digunakan untuk mengumpulkan data relevan mengenai tingkat penyesuaian diri dan derajat stres. Data dianalisis dengan menggunakan uji korelasi Spearman. Hasil penelitian menunjukkan bahwa ada hubungan negatif yang signifikan antara tingkat penyesuaian diri terhadap tuntutan akademik dengan tingkat stres pada mahasiswa baru dengan nilai $\mathrm{p}$ sebesar 0,001 $(\mathrm{p}<0,05)$ dan nilai $\mathrm{r}$ sebesar $-0,697$.

Kata kunci : mahasiswa kedokteran; penyesuaian diri; tuntutan akademik; stres. 


\section{2 | Jurnal Psikologi Pendidikan \& Konseling Vol. 4 No.1 Juni 2018}

\section{PENDAHULUAN}

Mahasiswa baru merupakan status yang disandang oleh seseorang di tahun pertama kuliahnya. Pada awal menempuh pendidikan di perguruan tinggi, mahasiswa dihadapkan pada berbagai macam tantangan dan perubahan dalam hidup. Ini disebabkan oleh adanya perbedaan sifat pendidikan di Sekolah Menengah Atas (SMA) dan perguruan tinggi, meliputi perbedaan kurikulum dan sistem pembelajaran, disiplin, serta hubungan antara mahasiswa dan dosen (Zubir, 2012). Santrock menjelaskan bahwa masa transisi dari sekolah menuju ke perguruan tinggi melibatkan suatu perpindahan menuju struktur sekolah yang lebih besar dan lebih impersonal, meliputi interaksi dengan teman sebaya, yang berasal dari latar belakang geografis dan etnis yang beragam, ditambah pula dengan adanya tekanan untuk mencapai prestasi akademik, seperti memperoleh nilai yang baik (Nur, 2015).

Selain merupakan perguruan tinggi swasta tertua di Medan, Universitas Islam Sumatera Utara (UISU) yang telah ada sejak 7 Januari 1952 juga merupakan perguruan tinggi pertama yang berdiri diluar pulau Jawa. UISU terdiri dari sembilan Fakultas, dan salah satunya Fakultas Kedokteran. Beberapa tahun belakangan ini, Fakultas Kedokteran menerapkan kurikulum baru. Selain berbeda dengan kurikulum sebelumnya, kurikulum ini juga berbeda dengan kurikulum pada fakultas lain. Kurikulum tersebut dikenal dengan sebutan Kurikulum Berbasis Kompetensi (KBK), meliputi beberapa kegiatan, yaitu small group discussion (SGD), kuliah pakar, praktikum, lab skills, panel experts, dan muatan lokal Sistem pembelajaran ini juga menuntut mahasiswa menjadi lebih aktif (Lubis, dkk, 2014).

Memasuki dunia perkuliahan merupakan suatu perubahan besar dalam hidup seseorang. Menurut Gail, Evans, dan Bellerose, pada masa transisi ini, individu dituntut untuk mampu menyesuaikan diri dengan berbagai aspek kehidupan secara bersamaan. Selanjutnya, Chinckering dan Schlosberg juga menambahkan bahwa mahasiswa yang baru menyelesaikan pendidikan SMA dan kemudian memasuki kehidupan perguruan tinggi lebih banyak mengalami kesulitan dalam menyesuaikan diri (Zubir, 2012).

Penelitian mengenai kondisi psikologis mahasiswa baru pernah dilakukan di beberapa universitas. Tahun 2001, Voitkane melakukan penelitian terhadap 607 orang mahasiswa tahun pertama Universitas Latvia, didapati sekitar 52.6 persen mahasiswa mengalami kesulitan dalam menghadapi hubungan baru (Sari, 2016). Selanjutnya hasil penelitian Nur (2015), di Universitas Padjajaran (UNPAD) menunjukkan bahwa sekitar 60 persen mahasiswa merasa belum dapat menyesuaikan diri dengan tuntutan akademik dengan baik. Hal ini dikarenakan kesulitan mereka dalam menyelesaikan tugas akademik, kesulitan menjalani hubungan dengan teman baru, belum terbiasa dengan sistem perkuliahan dan masih sangat bergantung dengan orang tua. Hal yang sama juga diperoleh dari penelitian yang dilakukan Shafira (2015), bahwa sekitar 56.6 persen mahasiswa baru merasa sedih, kesepian dan ketakutan ketika pertama kali tinggal jauh dari orang tua. Saat itu, mahasiswa yang tinggal jauh dari orang tua dituntut untuk mulai mampu mengatur hidupnya sendiri, menyesuaikan diri dengan teman dan kegiatan baru serta menghadapi perubahan budaya asal dengan budaya tempat tinggal baru.

Kegagalan individu dalam melakukan penyesuaian diri dalam bidang pendidikan dapat menyebabkan individu mengalami gangguan psikologis, salah satunya merasakan stres. Lingkungan perguruan tinggi membuat mahasiswa baru mengalami perubahan dan menuntut mereka untuk melakukan penyesuaian terhadap lingkungan baru tersebut. Tuntutan ini dapat menimbulkan permasalahan, yaitu mampu membuat mahasiswa menjadi stres (Handono dan Bashori, 2013).

Berbagai penelitian telah menunjukkan bahwa mahasiswa kedokteran lebih banyak mengalami stres yang tinggi dibandingkan dengan mahasiswa program studi di sektor non medis (Legiran, Zalili dan Bellinawati, 2015). Tahun 2006, Stephani juga melakukan penelitian terhadap mahasiswa kedokteran di Universitas California, Amerika dan didapati sekitar 51 persen mahasiswa mengalami stres (Suganda, 2014). Hasil yang sama juga didapati oleh Abdulghani yang melakukan penelitian pada mahasiswa kedokteran tahun pertama di Arab Saudi dan ditemukan sebesar 74.2 persen mahasiswa kedokteran tahun pertama mengalami stres tinggi, dan pada tahun berikutnya prevalensinya menurun menjadi 69.8 persen dan 48.6 persen (Oktovia, dkk. 2012). Sama halnya dengan penelitian yang dilakukan di Zianudin Medical University terhadap 252 mahasiswa dan diperoleh kesimpulan bahwa terjadi penurunan tingkat stres mahasiswa 
kedokteran pada tahun pertama, kedua, ketiga, dan keempat, secara berturut-turut sebesar 73 persen, 66 persen, 49 persen, dan 47 persen. Di Indonesia, penelitian dilakukan oleh Saqib dan Iman, menemukan bahwa prevalensi stres yang dialami mahasiswa baru sebesar 45.8 sampai 71.6 persen. Derajat stres mahasiswa tahun pertama lebih tinggi jika dibandingkan dengan mahasiswa tahun kedua, ketiga, dan keempat (Oktovia, dkk. 2012). Dengan kata lain, dapat dikatakan bahwa derajat stres pada mahasiswa kedokteran akan akan menurun seiring dengan kenaikan tingkat kuliah.

Stres dapat dianggap sebagai ancaman, yang dapat menyebabkan kecemasan, depresi, disfungsi sosial bahkan niat untuk mengakhiri hidup. Mahasiswa yang mengalami stres yang ekstrim atau terindikasi depresi membutuhkan perhatian dan penanganan serius karena dapat membawa efek yang kurang baik terhadap proses pembelajaran dan prestasi mahasiswa (Legiran, Zalili dan Bellinawati, 2015). Selain penelitian mengenai kaitan antara tingkat penyesuaian diri terhadap tuntutan akademik dan derajat stres, khususnya di lingkup mahasiswa baru FK UISU belum pernah dilakukan, data yang diperoleh dari penelitian ini nantinya juga akan dijadikan dasar untuk merencanakan metode yang tepat untuk mengembangkan kesiapan psikologis mahasiswa baru sehingga mampu memberikan performa maksimal. Karenanya, peneliti tertarik untuk mengetahui hubungan tingkat penyesuaian diri terhadap tuntutan akademik dan derajat stress pada mahasiswa baru, FK UISU, T.A 2016-2017.

\section{METODE}

Penelitian menggunakan pendekatan kuantitatif yang bersifat korelasional dengan melibatkan seluruh mahasiswa baru FK UISU T.A 2016-2017, yang saat itu berjumlah 49 orang. Keterbatasan jumlah mahasiswa baru mendorong peneliti menggunakan teknik total sampling. Penelitian dilaksanakan di FK UISU, yaitu di Jalan Sisingamangaraja XII no. 2A Medan, mulai bulan Mei tahun 2016 hingga Januari tahun 2017.

Dalam penelitian ini, ada dua variabel, yaitu (1) Tingkat penyesuaian diri, yang didefinisikan sebagai respon mental dan tingkah laku mahasiswa untuk bereaksi terhadap tuntutan, baik yang berasal dari dalam diri sendiri maupun tugas formal yang berhubungan dengan tugas akademik sehingga mampu survive, dan memperoleh kesejahteraan jasmaniah dan rohaniah, juga dapat mengadakan relasi yang memuaskan dengan tuntutantuntutan sosial yang diukur melalui melalui Student Adaptation to College Questionnaire (SACQ) test dan; (2) derajat stres adalah kondisi psikologis yang muncul akibat ketidakseimbangan antara harapan dan kenyataan, erat kaitannya tuntutan yang harus dihadapi, diukur melalui Kessler Psychological Distress Scale (K10 Test).

Peneliti menggunakan dua instrumen untuk mengumpulkan data. Pertama, SACQ digunakan untuk mengumpulkan data relevan mengenai tingkat penyesuaian diri. Instrumen ini diadaptasi dari Baker dan Siryk (1984), terdiri dari 66 item pernyataan dan disusun berdasarkan empat dimensi college adjustment, yaitu academic adjustment, social adjustment, personal emotional adjustment, dan instutional adjustment. SACQ telah diuji reliabilitasnya dengan menggunakan cronbach alpha dan diperoleh indeks reliabilitas sebesar 0.909, sedangkan nilai vadilitas diatas 0.2 , dengan melihat nilai corrected item total correlation. SACQ juga telah banyak digunakan pada penelitian untuk mengukur kesuksesan penyesuaian diri di perguruan tinggi. Kedua, K10 Test merupakan pengukuran sederhana psychological distress yang dikembangkan oleh Kessler dan Mroczek, digunakan untuk mengumpulkan data mengenai derajat stres mahasiswa baru. Sama halnya dengan SACQ, K10 Test yang terdiri dari 10 item pernyataan ini, juga telah diuji reliabilitas serta validitasnya dengan menggunakan teknik yang sama dan diperoleh indeks reliabilitas sebesar 0.881 , nilai validitas diatas 0.2 (Zubir, 2012).

Selanjutnya dilakukan analisis bivariate untuk mengetahui hubungan antara dua variabel yang bersangkutan, yaitu penyesuaian diri terhadap tuntutan akademik dan derajat stres. Analisis data juga dilakukan dengan menggunakan bantuan program komputer. Kedua variabel menunjukkan data tidak terdistribusi normal, sehingga uji hipotesis data dilakukan melalui uji korelasi Spearman. 
HASIL DAN PEMBAHASAN

Analisis data dilanjutkan dengan menggunakan uji korelasi Spearman dengan bantuan program komputer untuk mengetahui ada tidaknya hubungan antara tingkat penyesuaian diri dan derajat stres pada mahasiswa baru kedokteran UISU. Hasil uji analisis, secara rinci terlihat pada tabel ini:

Tabel 4.1 Derajat Stres Mahasiswa Baru Fakultas Kedokteran ditinjau dari Tingkat Penyesuaian Diri terhadap Tuntutan Akademik

\begin{tabular}{|c|c|c|c|c|c|c|}
\hline \multirow{3}{*}{ Tingkat Penyesuian Diri } & \multicolumn{4}{|c|}{ Derajat Stres } & \multirow[t]{2}{*}{ Nilai $P$} & \multirow[t]{2}{*}{ Nilai $r$} \\
\hline & \multicolumn{2}{|c|}{ Tinggi } & \multicolumn{2}{|c|}{ Rendah } & & \\
\hline & $\mathrm{n}$ & $\%$ & $\mathrm{n}$ & $\%$ & \multirow{3}{*}{0,001} & \multirow{3}{*}{$-0,697$} \\
\hline Baik & 7 & 14 & 13 & 27 & & \\
\hline Buruk & 23 & 46 & 6 & 13 & & \\
\hline
\end{tabular}

*Uji korelasi Spearman $(\mathrm{p}<0,05)$

Dari tabel diatas terlihat nilai $\mathrm{p}$ sebesar $0,001(\mathrm{p}<0,05)$ dan nilai $\mathrm{r}$ sebesar $-0,697$, yang berarti bahwa terdapat hubungan negatif yang signifikan antara tingkat penyesuaian diri terhadap tuntutan akademik dengan tingkat stres pada mahasiswa baru FK UISU T.A 2016-2017. Dengan kata lain, dapat dikatakan bahwa semakin baik tingkat penyesuaian diri terhadap tuntutan akademik seorang mahasiswa, maka akan semakin rendah derajat stres yang dialaminya. Terlihat pula bahwa mayoritas mahasiswa baru kurang mampu menyesuaikan diri dengan tuntutan akademik, diperkirakan mereka kurang mampu menyelaraskan kebutuhan sehingga merasakan stres. Ini sejalan dengan pendapat Christyanti, Mustami'ah dan Sulistiani bahwa apabila individu mampu menyesuaikan diri dengan lingkungannya berarti individu tersebut mampu menyelaraskan kebutuhannya dengan tuntutan lingkungan sehingga tidak merasa stres dalam dirinya (Christyanti, Mustami'ah dan Sulistiani, 2010).

Selanjutnya, peneliti juga menemukan gambaran umum mengenai tingkat penyesuaian diri mahasiswa baru, yang tertuang dalam tabel dibawah ini:

Tabel 4.2 Tingkat Penyesuaian Diri

Mahasiswa Baru FK UISU T.A 2016/2017

\begin{tabular}{cccc}
\hline Interval & Tingkat & $\begin{array}{c}\text { Frekuensi } \\
(\mathrm{n})\end{array}$ & $\begin{array}{c}\text { Persentase } \\
(\%)\end{array}$ \\
\hline $185-206$ & Baik & 30 & 61 \\
$133-184$ & Buruk & 19 & 39 \\
\hline
\end{tabular}

Tabel tersebut menunjukkan bahwa mayoritas mahasiswa baru FK UISU T.A 2016/2017 mampu menyesuaikan diri dengan tuntutan akademik, atau dengan kata lain dikategorikan memiliki tingkat penyesuaian diri yang baik. Hasil penelitian ini berbeda dengan hasil penelitian sebelumnya. Diperkirakan institusi pendidikan sebagai tempat menimba ilmu telah memberikan kepuasaan kepada mahasiswa sehingga terbangun kelekatan antara mahasiswa dengan kampus maupun kegiatan perkuliahan. Pada akhirnya, ini berpengaruh pada keinginan mereka untuk tetap bertahan dan melanjutkan perkuliahan. Hal ini didukung oleh pendapat Christyanti, Mustami'ah dan Sulistiani bahwa kondisi lingkungan sekolah (perguruan tinggi) merupakan salah satu faktor yang mempengaruhi penyesuaian diri terhadap tuntutan akademik. Kepuasan individu terhadap lingkungan ataupun kegiatan perkuliahan secara umum, dan kepuasan terhadap kegiatan perkuliahan secara khusus mempengaruhi keputusan individu tersebut untuk survive dan melanjutkan pendidikan, yang pada akhirnya, hal ini juga berpengaruh pada terbentuk kelekatan antar diri individu dengan kegiatan perkuliahan (Christyanti, Mustami'ah dan Sulistiani, 2010).

Gambaran umum mengenai derajat stres yang dialami mahasiswa baru, secara rinci dapat dilihat pada tabel berikut ini:

Tabel 4.3 Derajat Stres Mahasiswa Baru FK UISU T.A 2016/2017

\begin{tabular}{cccc}
\hline Interval & Derajat & $\begin{array}{c}\text { Frekuensi } \\
(\mathrm{n})\end{array}$ & $\begin{array}{c}\text { Persentase } \\
(\%)\end{array}$ \\
\hline $24-40$ & Tinggi & 20 & 41 \\
$15-23$ & Rendah & 29 & 59
\end{tabular}

Tabel diatas menunjukkan bahwa mahasiswa baru FK UISU lebih banyak mengalami stres pada derajat rendah dibandingkan dengan derajat lainnya. Holroyd 
dan Lazarus menyatakan bahwa kognitif memiliki peran yang signifikan dalam reaksi stres dan biasanya dikonsepkan dalam dua proses interaksi, yaitu aprraisal dan coping. Appraisal menentukan apakah suatu situasi dianggap stressful dan perubahan cognitive aprraisal seseorang dapat mereduksi stres. Jadi, apabila individu merasa bahwa suatu situasi sebagai sesuatu yang stressful maka coping dibutuhkan dan sebaliknya apabila seseorang menganggap suatu situasi bukan merupakan sesuatu yang stressful maka coping tidak dibutuhkan. Situasi yang dirasakan stressful juga dapat diminimalisir melalui coping skills yang efektif (Lazarus dan Folkman, 1984). Terkait dengan temuan penelitian bahwa mahasiswa baru FK UISU, T.A 2016/2017 mengalami stres pada derajat rendah diperkirakan ada hubungannya dengan kognitif mahasiswa. Kemungkinan beberapa mahasiswa menilai perguruan tinggi sebagai lingkungan baru bukan merupakan situasi yang stressful sifatnya. Namun ada pula beberapa mahasiswa yang mungkin menilai situasi tersebut sebagai sesuatu yang stressful, tetapi mampu meminimalisir situasi stressful dengan menerapkan coping skills yang efektif.

\section{SIMPULAN DAN SARAN}

Penelitian ini menemukan bahwa terdapat hubungan negatif yang signifikan antara tingkat penyesuaian diri terhadap tuntutan akademik dengan tingkat stres pada mahasiswa baru FK UISU T.A 2016-2017. Penelusuran mengenai tipe coping skills yang dinilai efektif dapat meminimalisir situasi stressful dapat dijadikan sebagai pertimbangan untuk penelitian selanjutnya.

Selain itu, bagi peneliti yang tertarik dengan tema yang sama juga sebaiknya mempertimbangkan besar sampel sehingga hasil penelitian dapat digeneralisasikan untuk tingkat populasi yang lebih luas.

\section{DAFTAR RUJUKAN}

Christyanti, D.; Mustami'ah, D.; Sulistiani, W. (2010). Hubungan antara Penyesuaian Diri terhadap Tuntutan Akademik dengan Kecenderungan Stres pada Mahasiswa Fakultas Kedokteran Universitas Hang Tuah Surabaya, Universitas Hang Tuah Surabaya, hal: 2.
Handono, O.T.; Bashori, K. (2013). Hubungan Antara Penyesuaian Diri Dan Dukungan Sosial Terhadap Stres Lingkungan pada Santri Baru, Universitas Ahmad Dahlan, hal 3.

Lazarus, R.; Folkman, S. (1984). Stress, appraisal and coping. New York: Springer Publishing Company.

Legiran, A.; M. Zalili.; Bellinawati, Nedya. (2015) Faktor Resiko Stres dan Perbedaannya pada Mahasiswa Berbagai Angkatan di Fakultas Kedokteran Universitas Muhammadiyah Palembang. Jurnal Kedokteran dan Kesehatan, Volume 2, No 2, April 2015: 197-202.

Lubis, dkk. (2014). Buku Panduan Akademik Tahun Ajaran 2014/2015. Medan: Fakultas Kedokteran Universitas Islam Sumatera Utara, hal: 1; 43-59

Nur, A.R. 2015. Hubungan Antara Kemandirian Dengan Penyesuaian Diri Dalam Lingkungan Kampus Pada Mahasiswa, Universitas Padjajaran, hal: 3.

Oktovia, W., dkk. 2012. Hubungan Kecerdasan Emosional Dengan Tingkat Stres Pada Mahasiswa Tahun Pertama Fakultas Kedokteran Universitas Riau, Universitas Riau, hal: 2.

Sari, D.P. 2016. Hubungan Sense Of Humor dengan Personal Adjustment pada Mahasiswa Rantau Tahun Pertama USU, Universitas Sumatera Utara, hal: 7

Shafira, F. 2015. Hubungan Antara Kematangan Emosi dengan Penyesuaian Diri pada Mahasiswa Perantau,Universitas Muhamadiyah Surakarta, hal: 4.

Suganda, K.D. 2014. Tingkat Stres Pada Mahasiswa Tahun Pertama Fakultas Kedokteran Universitas Sumatera Utara Angkatan 2013, Universitas Sumatera Utara, hal: 2-3.

Zubir, D.M. 2012. Hubungan Antara Psychological Well-Being dan College Adjustment pada Mahasiswa Tahun Pertama Universitas Indonesia,Universitas Indonesia, hal: 13 . 